\title{
Synthesis of some Novel Pyrazolo and Triazolo Quinolines from Coumarin Compounds
}

\author{
Adnan O. Omar \\ Shymaa S. Shawkat \\ Department of Chemistry \\ College of Science \\ University of Mosul
}

(Received 25/7/2011;Accepted 21/11/2011)

\begin{abstract}
Coumarin and its furo derivatives (psoralene and isopsoralene) are used as precursor for preparation of heterocyclic compounds. The 4-methyl-7-mthoxycoumarin, psoralene and substituted isopsoralene (II, III and IV) which are derived from 4-methyl-7hydroxycoumarin (I), when reacted with hydrazine hydrate through nucleophilic substitution reaction under basic condition give $\mathrm{N}$-amino-2-quinolone and its furo derivatives $(1,5$ and 9$)$ in good yields.

Reaction of these compounds (1,5 and 9) with methyl acetoacetate, ethyl acetoimidate or thiosemicarbazide, a new heterocyclic compounds will be formed pyrazolo-quinoline and it is furo derivatives (2,6 and 10); 1,2,4-triazolo-quinoline and its furo derivatives (3,7 and $11)$ and 1,2,4- triazolo-quinoline-2-thione (4,8 and 12) respectively.

The assigned structure of the prepared compounds were elucidated by the available physical and spectral methods IR, UV and ${ }^{1} \mathrm{H}-\mathrm{NMR}$.

Keywords: coumarin derivative, $\mathrm{N}$-amino-2-quinolone, pyrazolo and triazolo quinoline.

تشييد بهض مركبات البليرازولو والترليازولوكوينولين الجيةمن مشقلت الكومارن

\section{المانص}

لستخدم الكومارين ومشقاته من الفيوروكومارين مل البسورالين والايزوبسورالين بصفة مواد اولية لتحضير بعض المركبلت الحقية غير المتجلنة.

فقد لستخدت المركبلت (4-ميل -7 -ميثوكسي كومارين (II))، 6,4 - ثنائي مثيل بسورالين (III)

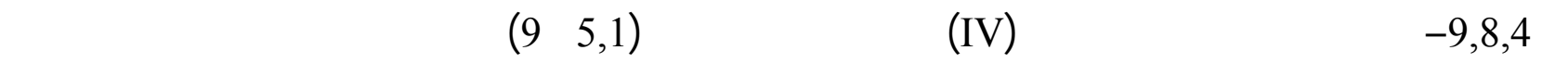
المائي في محط قاعدي عبر القاعل التعويضي النيكلوفيلي لتكوين مركبلت N-المينو-2 - كوينولون ومشقاته من الفيوروكوينولون. عند تفاعل هذه المركبلت (5,1 و9) مع لميتولسيتلت المثل، لميتوايميدات المثيل او الثايوسيميكاربازيد تتكون مركبلت حلقية غير متجلنة منمجة جدية مل البايرازولو - كوينولين
\end{abstract}


ومشقاته من الفيوروكوينولن (6,2 و10)، تراليازولو -كوينولين ومشقاته من الفيوروكوينولين (7,3 و11) او 4,2,1 - ترايازولوكوينولين -2 -ثايون ومشنقاته من الفيوروكوينولين (8,4 و12) على التوالي. م تشخيص المركبلت المحضرة بالطرائق الفيزيائية والطيفية المتيسرة IR, UV وطفيف الرنين النووين المغنطيسي.

الكاملت الفتلحية: مشققت الكومارين، N -لمينو -2 - كوينولون، بايرازولوكوينولن و ترايازولو كوينولين. INTRODUCTION

The formation of fused heterocyclic rings is an important task for heterocyclic chemists from various points of view.

Coumarin and it is derivatives represent one of the most active classes of compounds possessing a wide spectrum of biological activity. A review article dealing with the varied physiological activities of coumarin derivatives has been published describing their anticoagulant properties (Arora et al., 1963 ; Dirk et al., 2011 ; Ghulam et al., 2007), antibacterial (Ramachandra et al., 2010), antifungal (Soroush et al., 1999), antiinflammatory (Borges et al., 2005) and antitumor activities (Manfredini et al., 1997).

The nucleophilic substitution reaction of coumarin with ammonia derivatives (amine, hydrazine, phenyl hydrazine, ... etc.) proceed through ring opening of the pyrone ring and recyclized to form N-substituted-2-quinolone derivatives (Katritizky et al., 1984). The reaction of coumarin with hydrazin hydrate in the presence of pyridine gives N-amino-2quinolone and its derivatives (Al-Bayati et al., 2010).

The quinolone derivatives are important due to their biological and pharmaceutical activities such as antitumor (Joseph et al., 2002), antimalarial (Xiao et al., 2001), antiplatelet (Nishi et al., 2000), antidepressant (Oshiro et al., 2000), antiulcer (Banno et al, 1988), antioxidant agent (Al-Omer et al., 2006) and herbicide activities (Khan et al., 2003). Also anumber of quinolone compounds are important as synthone in organic synthesis (Godard et al., 1994).

Pyrazole and triazole derivatives are also important due to their biological activities (Michael et al., 1996), antimycotic (Liming et al., 2006) and widely used in both human and veterinary therapy and as agricultural fungicides and human fungal disease (Menegola et al., 2001).

In this presentation, a series of new heterocyclic compounds pyrazole and triazole were prepared from coumarin and it is furo derivatives. The furo coumarin compounds (III and IV) are prepared as in the published research (Traven et al., 2003 ; Adriana et al., 2002) by starting from 4-methyl-7-hydroxycoumarin (I) which is alkylated with allyl bromide, the obtained ether were subjected to a Claisen rearrangement followed by cyclization of the rearrangement product in the presence of acid.

\section{EXPERIMENTAL}

Melting points were measured on electrothermal Gallen Kamp melting points apparatus and uncorrected. Infrared (FT.IR.) spectra were recorded as $(\mathrm{KBr})$ disk using a Brucker FT.IR. 
spectrophotometer 2003. Ultraviolet (UV) spectra were preformed on Shimadzu UV-Visible spectrophotometer, UV-1650. ${ }^{1} \mathrm{H}-\mathrm{NMR}$ were recorded by Brucker $(300 \mathrm{MHz})$ in Jordan.

Synthesis of $\mathrm{N}$-amino-2-quinolone and it is furo derivatives (1,5 and 9) (Vinoda et al., 2004).

To a mixture of ( 1 mmole) of coumarin compounds (II, III and IV) in (10 ml) pyridine, hydrazine hydrate $(95 \%)(10 \mathrm{ml})$ was added drop wise with stirring at room temperature. The mixture was refluxed for $(2 \mathrm{hrs})$, then cooled, and the solid product was filtered off, washed with water then recrystallized from ethanol. The physical and spectral data were shown in Table (1).

Synthesis of pyrazoloquinoline and it is furo derivatives (2,6 and 10) (Shelton et al., 2003).

In the firsr step:

A mixture of (1 mmole) of $\mathrm{N}$-amino-2-quinolone (1,5 and 9), methyl acetoacetate (10 mmole) and few drops of p-toluene sulphonic acid was stirrered for $(4 \mathrm{hrs})$ at $130^{\circ} \mathrm{C}$ then cooled and the solid product was collected by filtration, washed with water and recrystallized from ethanol.

In the second step: the product from the first step $(1 \mathrm{mmole})$ was dissolved in $(10 \mathrm{ml})$ DMF then sodium acetate $(0.1$ mmole $)$ was added. The mixture was refluxed for $(1 \mathrm{~h})$, cooled and the solid product was collected by filtration, washed with water and recrystallized from ethanol. The physical and spectral data were shown in Table (1).

Synthesis of triazoloquinoline and it is furo derivatives (3,7 and 11) (Konda et al., 2010; Abd-El-Fatah et al., 2010).

Ethyl acetimidate $(1$ mmole) [which prepared according to the published procedure (Vogel, 2007)] was added to a mixture of $(30 \mathrm{ml}) 10 \%$ sodium carbonate solution and (30 $\mathrm{ml})$ toluene to form two layers. The mixture was shaken then the organic layer was separated. To the organic layer $\mathrm{N}$-amino-2-quinolone (1, 5 and 9) (1mmole) was added, then refluxed for ( $3 \mathrm{hrs}$ ), cooled and the solid product was filtered, washed with water and recrystallized from ethanol. The physical and spectral data were shown in Table (1).

\section{Synthesis of triazoloquinoline-2-thione and it is furo derivatives (4,8 and 12) (Hussain et al., 1997).}

A mixture of coumarin compounds or it is furo derivatives (II, III and IV) (1 mmole) and thiosemicarbazide $(1 \mathrm{mmole})$ in DMF $(20 \mathrm{ml})$. was refluxed for $(3 \mathrm{hrs})$. The reaction mixture was cooled and the solid product was filtered off, washed with water and recrystallized from ethanol. The physical and spectral data were shown in Table (1).

\section{RESUITS AND DISCUSSION}

The synthetic pathway leading to the title compounds is given in secheme (1). The key intermediate $\mathrm{N}$-amino-2-quinolone and it is furo derivatives (1,5 and 9) could be prepared by the reaction of coumarin derivatives with hydrazine hydrate through ring opening of pyrone ring then recyclized to form $\mathrm{N}$-amino-2-quinolone derivatives as in (eq. 1) (Youssef et al., 2006). 


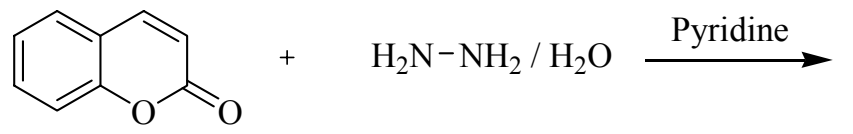<smiles>Cn1c(=O)ccc2ccccc21</smiles>
(eq. 1) The mechanism for this reaction is nucleophilic substitution $\mathrm{NH}_{2}$ through the attacking the carbonyl carbon atom by the unshared pair of electrons of nitrogen atom in hydrazine hydrate. This step is companied by ring opening and then recyclized of the intermediate gives the $\mathrm{N}$-amino-2-quinolone compounds.

The structure of compounds (1,5 and 9) was established on the bases of spectral data. Their IR spectra display absorption bands at $\left(1645,1665\right.$ and $\left.1662 \mathrm{~cm}^{-1}\right)$ related to the $(\mathrm{C}=\mathrm{O})$ bond stretching, and $\left(3270,3272\right.$ and $\left.3278 \mathrm{~cm}^{-1}\right)$ related to $(\mathrm{N}-\mathrm{H})$ bond stretching respectively.

The UV spectra showed absorption band at $\lambda_{\max }(227-238 \mathrm{~nm})$ due to the $\mathrm{n} \rightarrow \pi^{*}$ transition.

Treatment of compounds (1,5 and 9) with methyl acetoacetate in the presence of acid firstly afforded the hydrazide (as shown in eq. 2). These hydrazides were reacted with sodium acetate to give the carbanion which attacks the carbonyl carbon group of the pyridone ring with elimination of water molecule to give 3-acetyl-pyrazolo[1,5-a]quinoline-2-one derivatives $(2,6$ and 10$)$ respectively.<smiles>Cc1cc(=O)n(N)c(C)c1C</smiles><smiles>CC(=O)c1c(=O)[nH]n2c(C)c(C)c(C)cc12</smiles>

$(2,6$ and 10$)$<smiles>COC(=O)CC(C)=O</smiles><smiles></smiles><smiles>CC(=O)CC(C)C(N)=O</smiles>
(eq. 2)

The structure of the compounds (2, 6 and 10) was confirmed by means of IR, UV spectra in addition to the ${ }^{1} \mathrm{H}-\mathrm{NMR}$ spectrum for compound (2) as a sample for this series. The IR spectra show a (N-N) bond stretching at (1050, 1044 and $\left.1049 \mathrm{~cm}^{-1}\right)$ respectively and there are two different bonds related to the two carbonyl compounds (1691, 1696 and $\left.1701 \mathrm{~cm}^{-1}\right)$ for the acetyl carbonyl group respectively, and at $\left(1670,1685\right.$ and $\left.1682 \mathrm{~cm}^{-1}\right)$ related to the lactam carbonyl group respectively. Other bands were illustrated in table (1).

The UV spectra of these compounds showed $\lambda_{\max }$ bands at $(245-255 \mathrm{~nm})$ due to the $\mathrm{n} \rightarrow \pi^{*}$ transitions.

The ${ }^{1} \mathrm{H}-\mathrm{NMR}$ spectrum of compound (2) shows the following peaks: $3.30 \mathrm{ppm}(\mathrm{s}, 3 \mathrm{H}$, $\left.\mathrm{CO}-\mathrm{CH}_{3}\right) ; 3.51 \mathrm{ppm}\left(\mathrm{s}, 3 \mathrm{H}, 5-\mathrm{CH}_{3}\right)$ and $3.70 \mathrm{ppm}\left(\mathrm{s}, 3 \mathrm{H},-\mathrm{OCH}_{3}\right)$. The $(\mathrm{NH})$ appears at 9.10 
ppm. The peak at $6.51 \mathrm{ppm}(\mathrm{s}, 1 \mathrm{H}, 4-\mathrm{CH})$, and the three aromatic protons appears at a range (m, 7.10-7.65 ppm).

The reaction of N-amino-2-quinolones (1, 5 and 9) with ethyl acetimidate afforded the three derivatives of triazoloquinoline (3, 7 and 11), as in eq. (3).<smiles>CCOC(C)=N</smiles>

The structure of the compounds (3, 7 and 11) was identified by using IR, UV spectra in addition to the ${ }^{1} \mathrm{H}-\mathrm{NMR}$ spectrum for compound (7) as a sample for this series. The main bands in the IR spectra as in table (1) indicates the formation of $(\mathrm{C}=\mathrm{N})$ band due to appearance of bands at $\left(1661,1677,1668 \mathrm{~cm}^{-1}\right)$ respectively, also indicate the disappearance of the carbonyl group absorption band. The UV spectra for these compounds showed $\lambda_{\max }$ at (247-256 nm) due to the $\mathrm{n} \rightarrow \pi^{*}$ transition.

The ${ }^{1} \mathrm{H}-\mathrm{NMR}$ spectrum of compound (7) showed a multiplet peaks in a range (3.20$3.91 \mathrm{ppm})(9 \mathrm{H})$ for the three methyl groups, $6.51 \mathrm{ppm}(\mathrm{s}, 1 \mathrm{H}, 4-\mathrm{CH})$ and $6.80 \mathrm{ppm}(\mathrm{s}, 1 \mathrm{H}$, $8-\mathrm{CH})$, the peaks of the two aromatic protons appear in the range of (7.11-7.51 ppm). Coumarin itself and its furo derivatives react with other amino derivatives like thiosemicarbazide through nucleophilic displacement to form triazoloquinoline-thione derivatives (4, 8 and 12) as in eq. (4).

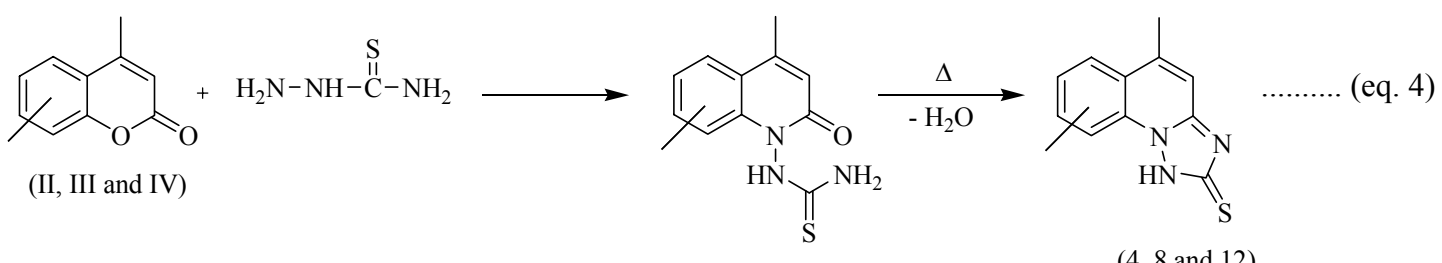

The structure of the compounds (4, 8 and 12) were confirmed by using IR, UV spectra in addition to the ${ }^{1} \mathrm{H}-\mathrm{NMR}$ spectrum for compound (12) as a sample for this series. The main absorption bands in the IR spectra as in table (1) indicate that the $(\mathrm{C}=\mathrm{N})$ band absorbed at $\left(1636,1616\right.$ and $1622 \mathrm{~cm}^{-1}$ ) respectively, and showed a disappearance of the carbonyl group absorption band. Other absorption band at $\left(1395,1389\right.$ and $1388 \mathrm{~cm}^{-1}$ ) related to $(\mathrm{C}=\mathrm{S})$ respectively. The $(\mathrm{N}-\mathrm{H})$ bond stretching appears at $(3257,3220$ and 3205 $\mathrm{cm}^{-1}$ ) respectively. Furthermore in the UV spectra of these compounds showed maximum absorption $\lambda_{\max }$ at $(255-278 \mathrm{~nm})$ this was attributed $\mathrm{n} \rightarrow \pi^{*}$ transition.

The ${ }^{1} \mathrm{H}-\mathrm{NMR}$ spectrum of the compound (12) as a sample for this series shows three peaks of a nine protons of the three methyl groups at $(3.31,3.35$ and $3.75 \mathrm{ppm}) ; 6.50 \mathrm{ppm}$ $(\mathrm{s}, 1 \mathrm{H}, 4-\mathrm{CH})$ and the two aromatic protons appears as a doublet at (7.22 and $7.61 \mathrm{ppm})$. The $(\mathrm{NH})$ proton appears as singlet at $7.88 \mathrm{ppm}$. 
Table 1: The physical and spectral data of the prepared compounds.

\begin{tabular}{|c|c|c|c|c|c|c|c|c|c|}
\hline \multirow[b]{2}{*}{ No. } & \multirow[b]{2}{*}{$\mathbf{m} \cdot \mathbf{p}^{\circ} \mathrm{C}$} & \multirow{2}{*}{$\begin{array}{c}\text { UV } \\
\text { (MeOH) } \\
\lambda \max \mathbf{n m}\end{array}$} & \multicolumn{7}{|c|}{ IR $(\mathrm{KBr}) \mathrm{cm}^{-1}$} \\
\hline & & & $\mathbf{C}=\mathbf{O}$ & $\mathbf{C}=\mathbf{C}$ & $\mathbf{C}=\mathbf{N}$ & $\mathbf{C}=\mathbf{S}$ & $\mathbf{N}-\mathbf{N}$ & $\mathbf{N}-\mathbf{H}$ & $\mathbf{C}-\mathbf{O}-\mathbf{C}$ \\
\hline 1 & $193-195$ & 227 & 1645 & 1595 & $\ldots$ & $\ldots$ & 1105 & 3270 & 1150 \\
\hline 2 & $253-255$ & 245 & $\begin{array}{l}1670 \\
1691\end{array}$ & 1562 & $\ldots$ & $\ldots$ & 1115 & 3217 & 1155 \\
\hline 3 & $218-220$ & 247 & $\cdots$ & 1601 & 1661 & $\cdots$ & 1126 & 3182 & 1156 \\
\hline 4 & $117-119$ & 255 & $\cdots$ & 1591 & 1636 & 1395 & 1141 & 3257 & 1178 \\
\hline 5 & $240-242$ & 236 & 1665 & 1688 & $\cdots$ & $\cdots$ & 1184 & 3272 & 1235 \\
\hline 6 & $168-170$ & 251 & $\begin{array}{l}1685 \\
1696\end{array}$ & 1610 & $\cdots$ & $\cdots$ & 1176 & 3210 & 1126 \\
\hline 7 & $225-227$ & 253 & $\cdots$ & 1570 & 1677 & $\cdots$ & 1132 & 3196 & 1180 \\
\hline 8 & $222-224$ & 270 & $\cdots$ & 1589 & 1616 & 1389 & 1184 & 3220 & 1210 \\
\hline 9 & $167-169$ & 238 & 1662 & 1602 & $\ldots$ & $\ldots$ & 1173 & 3278 & 1232 \\
\hline 10 & $224-226$ & 255 & $\begin{array}{l}1682 \\
1701\end{array}$ & 1618 & $\ldots$ & $\ldots$ & 1138 & 3222 & 1138 \\
\hline 11 & $200-202$ & 256 & $\cdots$ & 1582 & 1668 & $\cdots$ & 1125 & 3217 & 1185 \\
\hline 12 & $153-155$ & 278 & & 1582 & 1622 & 1388 & 1112 & 3205 & 1177 \\
\hline
\end{tabular}


$\mathrm{a}=\mathrm{MeI}$

$\mathrm{b}=\mathrm{NH}_{2}-\mathrm{NH}_{2}$

$\mathrm{c}=$ Methyl acetoacetate

$\mathrm{d}=$ Ethyl acetimidate

$\mathrm{e}=$ Thiosemicarbazide<smiles>COc1ccc2c(C)cc3nc(=S)[nH]n3c2c1</smiles>

(4)

$\uparrow$

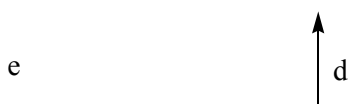

(I)

(II)<smiles>COc1ccc2c(C)cc3nc(C)nn3c2c1</smiles>

(3)

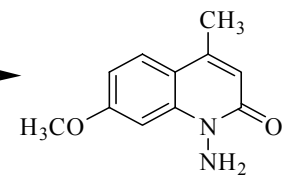

(1)

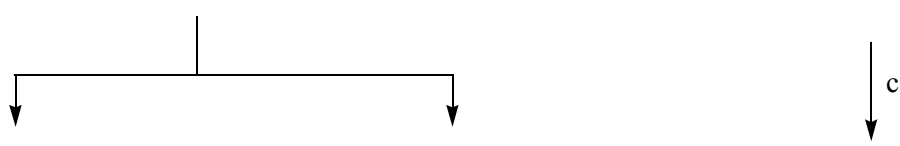<smiles>Cc1oc2ccc3c(C)cc(=O)oc3c2c1C</smiles><smiles>Cc1coc2cc3oc(=O)cc(C)c3cc12</smiles>

(III)

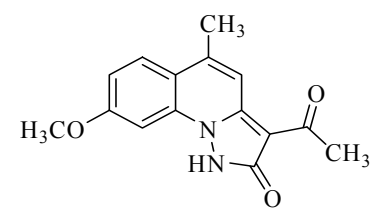

(2)

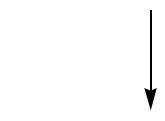

b

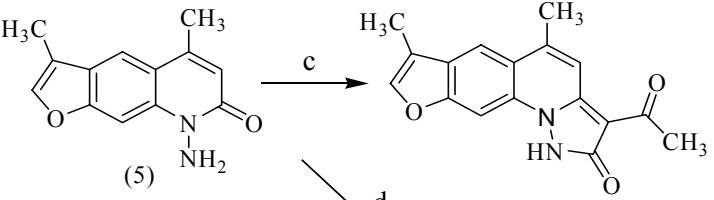

(6)
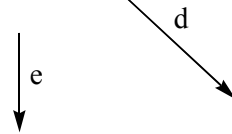<smiles></smiles>

(8)

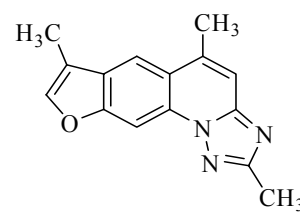

(7)

(11)

Scheme (1) 


\section{REFERENCES}

Abed El-Fattah, O; Abbas, E. M.; Ahmed, N. (2010). Synthesis and evaluation of some tetrahydropyrimidine derivatives as Antimicrobial; Aust. J. Basic and Appl. Sci., 4(1), 27-36.

Al-Bayati, R.; Mahdi, F. (2010). Synthesis of novel 2-quinolone derivatives. African $J$. Pure and Appl. Chem. 4(10), 228-232.

Al-Omer, M. A.; El-azab, A. S. (2006). Synthesis of some new 4(3H)-quinozolinone analogues. J. Saudi Chem. Sci. 10, 113-117.

Arora, R. B.; Mathur, C. N. (1963). Relationship between structure and anticoagulation activity of coumarin derivative; British J. Pharm. 20, 29-35.

Banno, K.; Fujioka, T.; Kikuchi, T. (1988). Studies on 2(1H)-uinolinone derivatives as neuroleptic agents, Synthesis and biological activites of (4-phenyl-1-iperazinyl)propoxy-2-(1H) quinolone derivative. Chem. Pharam. Bull., 36, 4377-4388.

Borges, F.; Roleira, F.; Milhazes, N. (2005). Simple coumarin and analogues in medicinal chemistry, Med. Chem., 12, 887-916.

Dirk, S.; Nicolas, V.B. (2011). Oral anticoagulation with coumarin derivatives and antiplatelet effect of clopidogrel. European heart J., 32, 804-817.

Ghulam, Q.; Nasim, H. R.; Zhi-Jin (2007). Synthesis herbicidal, fungicidal evaluation of 3(dichlorophenyl)-isocoumarin. J. Braz. Chem. Soc., 18(6), 171-179.

Govori, S.; Spahin, S.; Kalaj, V. (2010). Antimicrobial properties of newly Synthesized derivatives of coumarin., American J. of Biochem. and Biotec., 6(22), 275-284.

Joseph, B.; Darno, F.; Behard, A. (2002). 3-Aryl-2-quinolone derivative, Synthesis and characterization of invivo and invitro. J. Med. Chem., 45, 2534-2555.

Katritizky, A. R. ; Ress, C. W. (1984). "Comprehensive Heterocyclic Chemistry". 1st edn. Pergamon Press N. Y. pp. 3, 681.

Khan, I.; Hassan, G. ; Nizamudim, H. (1977). Synthesis and study of some triazolothiene derivatives. Indian, J. Chem., 36 B, 625-631.

Khan, I.; Hassan, G.; Ihssanullah, K. (2003). Efficacy of postemergence gerbicides for controlling weeds in canola. Asian J. Plant Sci. 2, 294-299.

Konda, S. G.; Khedker, V.T. (2010). Synthesis of some new 2-amino-3-cyano-4-aryl-6-(1naphthylamino) pyridine as antibacterial agent. J. Chem. Pharm. Res. 2(1), 187197.

Li-Ming, L.; Xiao, W. (2006). Use of poly functionalized ethylene Synthone convenient, Synthesis of biological active of $\mathrm{N}$-substituted pyrazoles and triazoles. Indian $J$. Chemistry, 45 B, 483-492.

Manfredini, S.; Daniele, S.; Roberto, F. (1977). Retinoic acid conjugates as potential antitumor agents. Synthesis and biological activity of conjugate aryl. $3(2 \mathrm{H})-$ furanone. J. Med. Chem.; 40(23), 3851-3857.

Menegola, E.; Brocciam, F. (2001). Antifungal triazoles induced formation invitro. Toxicol, 15(4), 421-427.

Michael, B. ; Pesvedso, B. (1996). Preparation of 1-hydroxypyrazoles and 1-hydroxy-1,2,3triazoles by dealkylation of pyrazole and triazole-N-oxide. Acta Chemical Scandinavica; 50, 549-553.

Nishi, T.; Kimura, Y. (2000). Research and development of cilostazole an antiplatelete agent. J. Med. Chem., 45, 1247-1260. 
Oshiro, Y.; Sakurai, Y. ; Sato, S. (2000). 3,4-Dihydro-2(1H)-quinolone as a novel antidepressant drug, Synthesis and pharmacology. J. Med. Chem. 43, 177-189.

Radoslaw, F.; Henrieta, S. ; Jana, D. (2009). Synthesis and study of novel coumarin derivatives potentially utilizable as memory media. Molecule, 14(12), 4838-4848.

Ramachandra, A.; Patil, N. ; Chourasia, P. (2010). Synthesis, Spectral studies and microbial activity of metal complex with coumarin derivative. Int. J. Appl. Biology and phar. Tech., 1(2), 566-574.

Shelton, M. (2003). Synthesis, antibacterial and antifungal activity of some pyrazole derivative. Chem. Heterocyclic Compounds, 39(4), 511-517.

Vinod, K.; Sarah, T. (2004). Synthesis and biological activity of substituted of 2,4,6Triazines. Acta Pharma., 54, 1-12.

Xiao, Z.; Waters, N. (2001). Design and Synthesis of PFMRK inhibitors as antimalarial agent. Bioorg. Med. Chem., 11, 2875-2878.

Youssef, A. (2006). Reaction of subs.-5-arylmethylene-1,3-thiazolidine., World J. Chem., 1(1), 10-19. 